\title{
Spontaneous lymphocyte-mediated (NK cell) cytotoxicity in systemic sclerosis: a comparison with antibody-dependent lymphocyte (K cell) cytotoxicity
}

\author{
J. K. WRIGHT, P. HUGHES, AND N. R. ROWELL \\ From the University Department of Medicine, Northern General Hospital, Sheffield, and the University \\ Department of Dermatology, the General Infirmary at Leeds
}

SUMMARY Spontaneous (NK cell) and antibody-dependent (K cell) cytotoxicity were investigated in 39 patients with systemic sclerosis (SS) and compared with that found in 52 normal controls. ${ }^{51} \mathrm{Cr}$-labelled Chang liver cells were used as targets in assays utilising both whole blood (WB) and peripheral blood mononuclear cells (PBM) as effectors. Patients with SS, who were severely affected by extensive visceral disease, were found to have significant impairment of both NK $(\mathrm{p}<0.005 ; \mathrm{p}<0.05)$ and $\mathrm{K}(\mathrm{p}<0.001 ; \mathrm{p}<0.05)$ cell cytotoxicity by both effector systems, when compared with normal controls. These findings, which seem to be part of a wider defect in cell-mediated immunity, may provide a possible explanation for the described association of malignancy with systemic sclerosis.

There is increasing evidence that immunological abnormalities are an important feature of systemic sclerosis. Humoral abnormalities, such as a high incidence of autoantibodies ${ }^{12}$ and rheumatoid factor ${ }^{3}$ have been recognised for some time. More recently interest in abnormalities of cell-mediated immunity has been stimulated by the description of increased lymphocyte cytotoxicity for cultured fibroblasts ${ }^{4}$ and the recognition of abnormalities of thymusdependent $(\mathrm{T})$ lymphocytes in patients severely affected by the disease. ${ }^{6}$ Further interest in cellmediated mechanisms has come from the realisation that graft-versus-host disease in both experimental animals ${ }^{7}$ and man can be followed by the development of scleroderma-like lesions. ${ }^{89}$ Recent studies have, however, failed to confirm the presence of increased lymphocyte cytotoxicity for cultured target cells. ${ }^{1011}$ The present investigation of spontaneous or natural killer (NK cell) lymphocyte cytotoxicity for Chang liver cells was undertaken, therefore, as the first stage of a series of investigations into cytotoxic mechanisms in systemic sclerosis.

\section{Materials and methods}

Thirty-nine patients with systemic sclerosis (34 women, 5 men; mean age $54 \cdot 8 \pm 12 \cdot 7$ years) were

Accepted for publication 16 June 1981.

Correspondence to Dr J. K. Wright, Department of Medicine, Clinical Sciences Centre, Northern General Hospital, Sheffield S5 7AU. studied. Five of the patients were receiving treatment with immunosuppressive drugs (prednisolone, penicillamine, or azathioprine). Raynaud's phenomenon and acrosclerosis were constant features, and all patients were assessed for the extent of systemic involvement by the disease using previously described investigational criteria ${ }^{6}$ to allocate points and so produce a 'disease score' for each patient. On this basis patients with systemic sclerosis were divided into categories of mild (disease score $0-5 ; 23$ women, 3 men; mean age $56.9 \pm 11.8$ years) and severe (disease score $6-17 ; 11$ women, 2 men; mean age $50.4 \pm 14.5$ years) disease.

The controls consisted of 52 normal healthy volunteers ( 25 women, 27 men; mean age $39 \cdot 8 \pm 14 \cdot 8$ years).

Spontaneous (NK cell) and antibody-dependent lymphocyte $(K$ cell) cytotoxicity. These assays were performed as previously described ${ }^{12}$ with ${ }^{51} \mathrm{Cr}$

Table 1 Correlation between whole blood (WB) and peripheral blood mononuclear cell (PBM) assays for NK and $K$ cell cytotoxicity in patients with systemic sclerosis $(n=39)$ and controls $(n=52)$

\begin{tabular}{lllc}
\hline Type of assay & Group studied & $r(W B$ vs PBM $)$ & $p$ \\
\hline NK cell & Systemic sclerosis & 0.44 & $<0.01$ \\
& Control & 0.27 & 0.05 \\
K cell & Systemic sclerosis & 0.64 & $<0.001$ \\
& Control & 0.69 & $<0.001$ \\
\hline
\end{tabular}




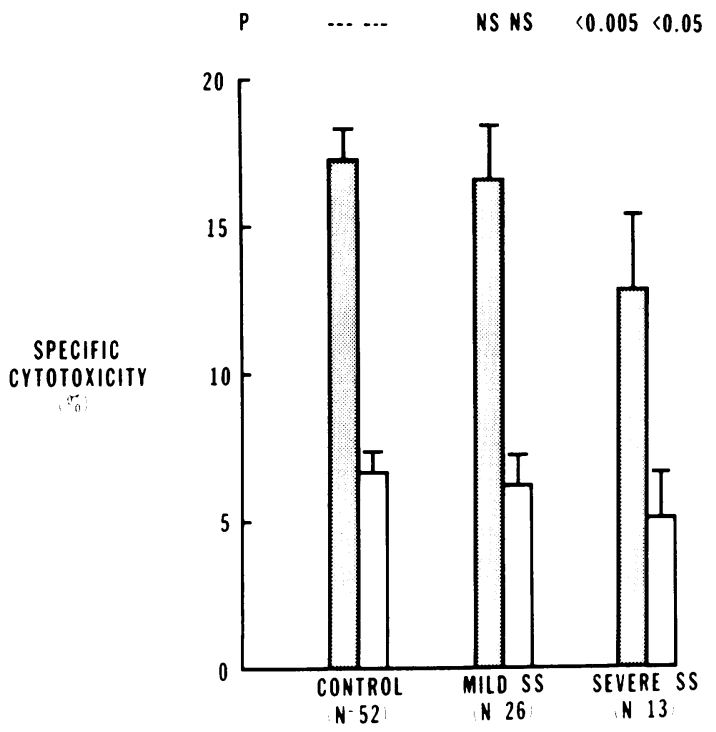

Fig. 1 Spontaneous lymphocyte-mediated (NK cell) cytotoxicity (mean \pm SEM) for Chang liver cells $(20000 \mathrm{ml})$ using both whole blood, $200 \mu \mathrm{l}(\mathbf{\square})$ and peripheral blood mononuclear cells, $500000 / \mathrm{ml}(\square)$ in patients with mild (n $=26)$ and severe $(n=13)$ systemic sclerosis $(S S)$ and normal controls $(n=52)$.

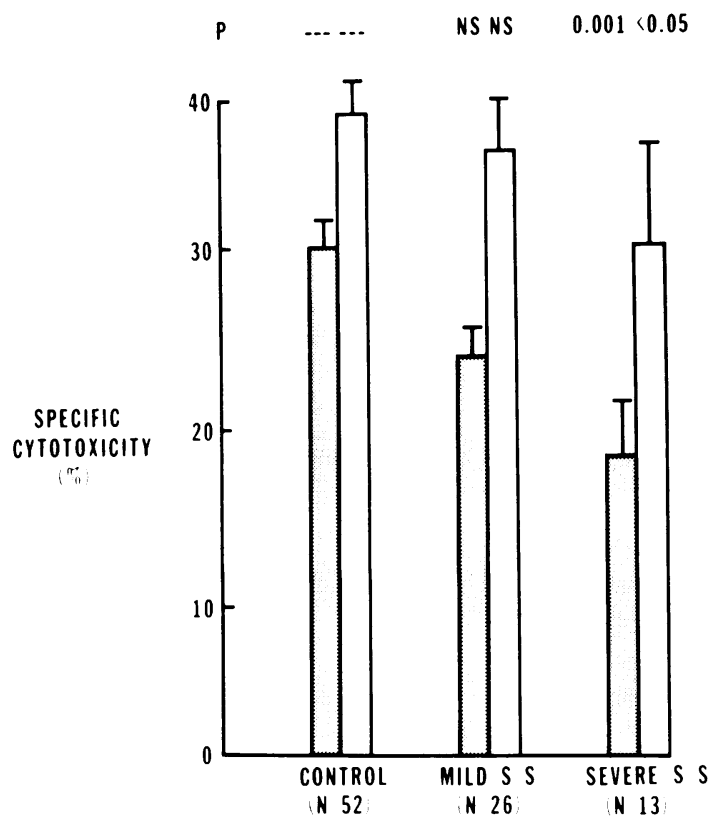

Fig. 2 Antibody-dependent lymphocyte ( $K$ cell) cytotoxicity (mean $\pm S E M)$ for Chang liver cells $(20000 / \mathrm{ml})$ using both whole blood, $200 \mu \mathrm{l}(\mathbf{E})$ and peripheral blood mononuclear cells, $5000001 \mathrm{ml}(\square)$ in patients with mild $(n$ $=26)$ and severe $(n=13)$ systemic sclerosis $(S S)$ and normal controls $(n=52)$.

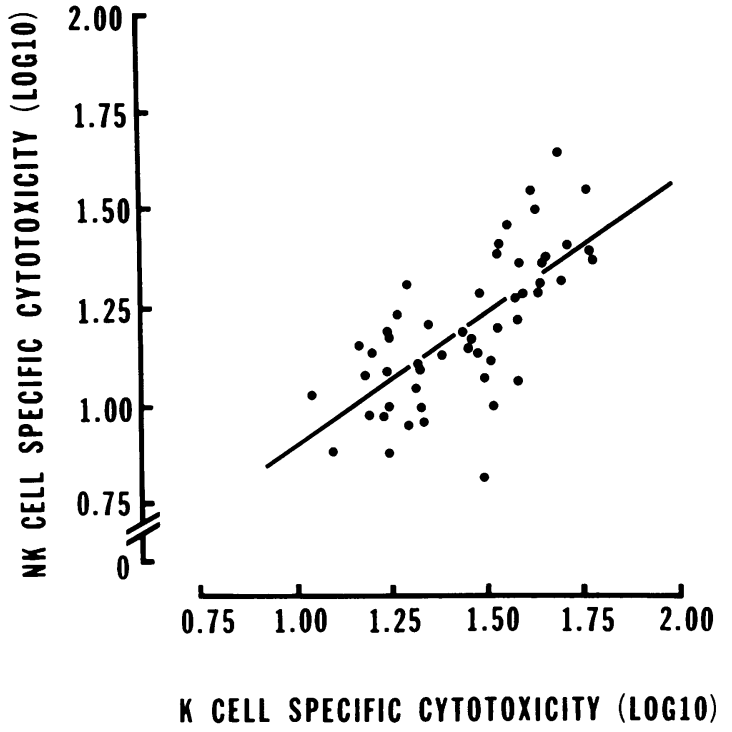

Fig. 3 The relationship between spontaneous lymphocyte-mediated (NK cell) cytotoxicity and antibody-dependent lymphocyte (K cell) cytotoxicity for Chang liver cells $(20000 / \mathrm{ml})$ using whole blood $(200 \mu \mathrm{l})$ in normal controls $(r=0 \cdot 70, p<0.001)$.

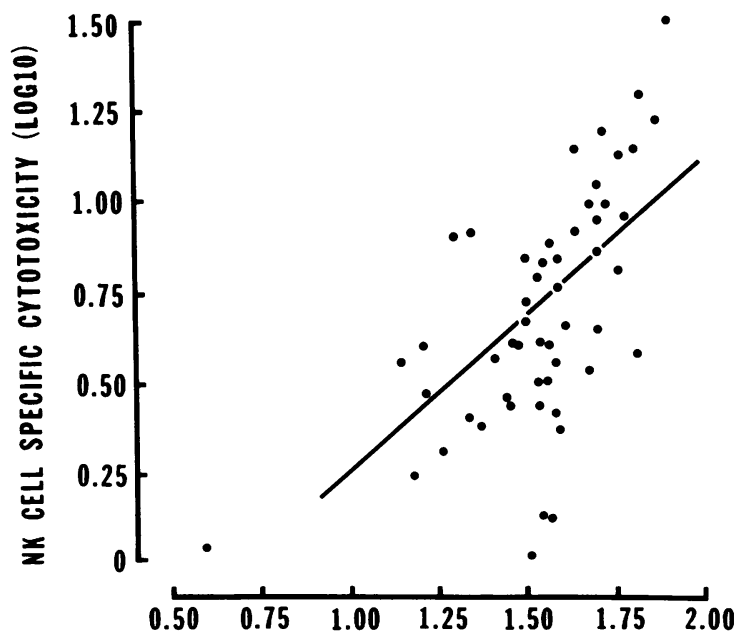

K CELL SPECIFIC CYTOTOXICITY (LOG10)

Fig. 4 The relationship between spontaneous lymphocyte-mediated ( $N K$ cell) cytotoxicity and antibody-dependent lymphocyte (K cell) cytotoxicity for Chang liver cells $(20000 / \mathrm{ml})$ using peripheral blood mononuclear cells $(500000 / \mathrm{ml})$ in normal controls $(r=0 \cdot 64, p<0 \cdot 001)$. 


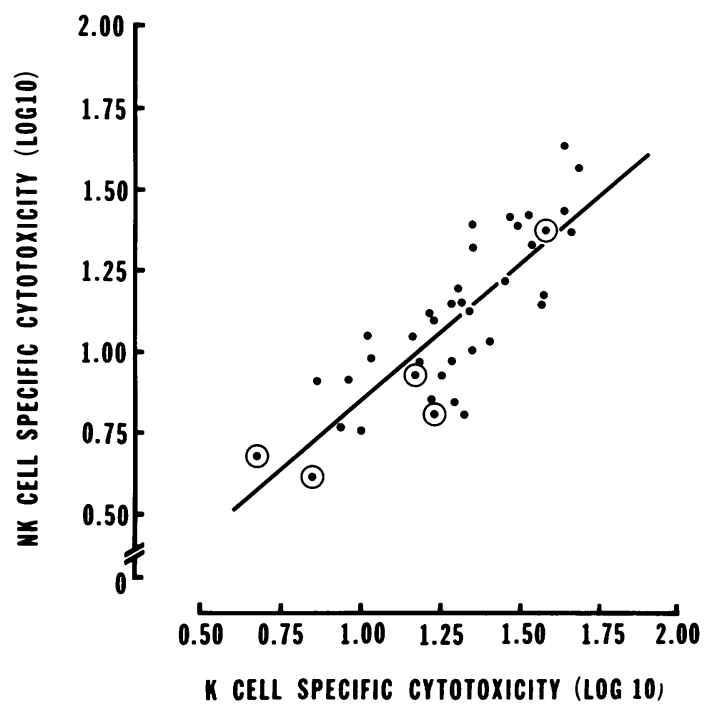

Fig. 5 The relationship between spontaneous lymphocyte-mediated (NK cell) cytotoxicity and antibody-dependent lymphocyte ( $K$ cell) cytotoxicity for Chang liver cells $(20000 / \mathrm{ml})$ using whole blood $(200 \mu \mathrm{l})$ in patients with systemic sclerosis $(r=0.82, p<0.001)$.

O Patients on immunosuppressive drugs.

labelled Chang liver cells as targets and both heparinised whole blood and purified peripheral blood mononuclear cells (PBM) as effector systems. NK cell cytotoxicity was expressed as percentage specific cytotoxicity after the 18 hour incubation of otherwise unmodified triplicate cultures of target and effector cells, while $\mathrm{K}$ cell cytotoxicity was similarly calculated for cultures to which had been added an optimal amount of rabbit anti-Chang cell serum. ${ }^{12}$

The cytotoxicity data were analysed by the Mann-Whitney ranking test. The relationship between NK cell and $\mathrm{K}$ cell cytotoxicity in both whole blood and PBM assays was examined by regression analysis following $\log _{10}$ conversion of the data.

\section{Results}

Spontaneous (NK cell) cytotoxicity. Comparison of NK cell cytotoxicity in both whole blood and PBM assays revealed some correlation which was more evident in patients with systemic sclerosis (Table $1, \mathrm{r}$ $=0.44, p<0.01$ ) than in the controls (Table $1, r=$ $0 \cdot 27, p=0 \cdot 05$ ). Nevertheless, patients with severe systemic sclerosis showed reduced NK cell cytotoxicity in both whole blood $(\mathrm{p}<0.005)$ and PBM assays $(p<0.05)$ when compared with the normal controls, whereas the corresponding cytotoxic responses of mildly affected patients showed no such reduction (Fig. 1).

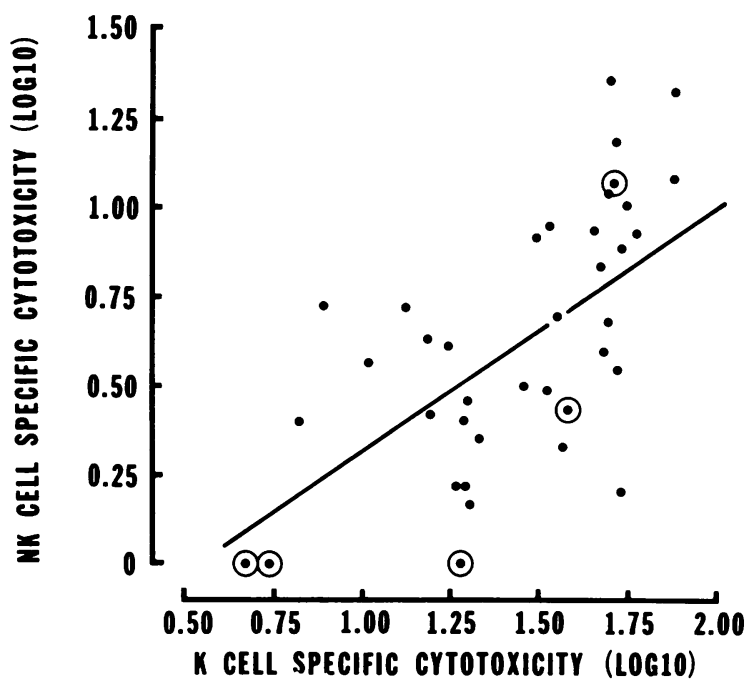

Fig. 6 The relationship between spontaneous lymphocyte-mediated (NK cell) cytotoxicity and antibody-dependent lymphocyte (K cell) cytotoxicity for Chang liver cells $(20000 / \mathrm{ml})$ using peripheral blood mononuclear cells $(500000 / \mathrm{ml})$ in patients with systemic sclerosis $(r=0.58, p<0.001)$. $\odot$ Patient on immunosuppressive drugs.

Antibody-dependent lymphocyte ( $K$ cell) cytotoxicity. Comparison of $\mathrm{K}$ cell cytotoxicity in both assays revealed better correlations in both patients (Table 1 , $r=0.64, p<0.001$ ) and controls (Table $1, r=0.69$, $\mathrm{p}<0.001)$ than in the case of NK cell cytotoxicity. Patients with severe systemic sclerosis again showed reduced $\mathrm{K}$ cell cytotoxicity in both whole blood $(\mathrm{p}=$ $0.001)$ and PBM assays $(\mathrm{p}<0.05)$ when compared with normal controls, in contrast, once more, to the normal responses of the mildly affected patients (Fig. 2).

Correlation of spontaneous (NK cell) and antibody-dependent lymphocyte ( $K$ cell) cytotoxicity. Comparison of NK cell and K cell cytotoxicity in both whole blood and PBM assays revealed good correlations in both controls (Fig. 3, $\mathrm{r}=0.70, \mathrm{p}<0.001$; Fig. $4, r=0.64, p<0.001$ ) and patients with systemic sclerosis (Fig. $5, \mathrm{r}=0.82$, $\mathrm{p}<0.001$; Fig. $6, \mathrm{r}=0.58$, $\mathrm{p}<0 \cdot 001)$.

\section{Discussion}

There is increasing evidence that spontaneous lymphocyte-mediated cytotoxicity against allogeneic target cells, both neoplastic and nonneoplastic, is produced by a heterologous group of lymphocytes (natural killer or NK cells) which are now regarded as predominantly $\mathrm{T}$ cell in origin. ${ }^{13}$ Fractionation studies have shown that this 'natural killing̀' is carried 
out most efficiently by $T$ cells lacking sheep red blood cell (SRBC) receptors and that increasing avidity of the SRBC receptor is associated with decreasing natural killer activity of the lymphocyte. In this spectrum of NK cell activity Fc receptor positive cells are generally more active than those lymphocytes lacking this receptor. ${ }^{14}$

With this background the findings of the present investigation are of 3-fold interest. Firstly, the conclusion that patients severely affected by systemic sclerosis have reduced NK cell activity is in accord with earlier observations of reduced $\mathrm{T}$ cell numbers and mitogen responsiveness in the disease. ${ }^{6}$ The maintenance of a good correlation between NK and $\mathbf{K}$ cell cytotoxicity in this study is in keeping with previous findings in normal controls, even though there is now evidence that the lymphocyte subpopulations mediating these 2 types of cytotoxicity are to some extent distinct ${ }^{14}$ and can be distinguished in some disease states. ${ }^{15}$

Secondly, the finding of impaired NK cell cytotoxicity in systemic sclerosis may also have a practical relevance. It has been suggested that NK cells are an important component of immune surveillance mechanisms against the development of tumours. ${ }^{16}$ There is growing support for this hypothesis in animal models ${ }^{17}{ }^{18}$ while in man depressed NK cell function (as well as other immunological abnormalities) and an increased incidence of malignancy are found in diseases such as Wiskott-Aldrich syndrome, ataxia telangiectasia, ${ }^{19}$ and kidney allograft recipients on immunosuppressive therapy. ${ }^{15}$ An increased incidence of pulmonary tumours ${ }^{20}$ and perhaps more general malignancy ${ }^{21}$ has also been reported in systemic sclerosis, and our current findings provide a possible explanation for these associations.

Finally, the observation of low NK cell activity in patients severely affected by systemic sclerosis may also be important in relation to assays for antigen specific $T$ cell cytotoxicity. Failure to take into account the 'background' effect of NK cell cytotoxicity may mask the detection of more specific $\mathrm{T}$ cell mediated effects. In illustration of this point Svedmyr and Jondal ${ }^{22}$ found that it was necessary to remove a proportion of the NK cells before it was possible to detect antigen specific $T$ cell cytotoxicity to $E B$ virus infected cells in patients with infectious mononucleosis. It is therefore possible that the failure to take into account this masking effect of NK cell activity may account for the failure of recent studies to confirm the earlier reports ${ }^{45}$ of increased lymphocyte cytotoxicity in systemic sclerosis. As both experimental $^{7}$ and human graft-versus-host disease ${ }^{89}$ may be complicated by sclerodermatous changes, further investigation of cytotoxic mechanisms in systemic sclerosis using fractionated lymphocyte sub- populations would certainly seem to be justified and could shed further light on the pathogenesis of the disorder.

This study was supported by a project grant from the Wellcome Trust.

\section{References}

${ }^{1}$ Beck J S, Anderson J R, Gray K G, Rowell N R. Antinuclear and precipitating autoantibodies in progressive systemic sclerosis. Lancet 1963; ii: 1188-90.

2 Alarcón-Segovia D, Fishbein E, Garcia-Ortigoza G, Estrada-Parra S. Uracil-specific anti-RNA antibodies in scleroderma. Lancet 1975 ; i: 363-6.

${ }^{3}$ Rothfield N F, Rodnan G P. Serum antinuclear antibodies in progressive systemic sclerosis (scleroderma). Arthritis Rheum 1968; 11: 607-17.

4 Trayanova T G, Sura V V, Svet-Moldavsky G J. Destruction of human cells in tissue culture by lymphocytes from patients with systemic lupus erythematosus. Lancet 1966 ; i: $452-4$.

5 Currie S, Saunders M, Knowles M. Immunological aspects of systemic sclerosis: in vitro activity of lymphocytes from patients with the disorder. Br J Derm 1971; 84: 400-9.

${ }^{6}$ Hughes P, Holt S, Rowell N R, Allonby I D, Dodd J K. The relationship of defective cell-mediated immunity to visceral disease in systemic sclerosis. Clin Exp Immunol 1977; 28: 233-40.

7 Statsny P, Stembridge V A, Ziff M. Homologous disease in the adult rat, a model for autoimmune disease. I. General features and cutaneous lesions. J Exp Med 1963; 118: 635-48.

8 Van Vloten W A, Scheffer E, Dooren L J. Localised scleroderma-like lesions after bone marrow transplantation in man. Br J Derm 1977; 96: 337-41.

9 Fenyk J R Jr, Smith C M, Warkentin P I, Krivit W, et al. Sclerodermatous graft-versus-host disease limited to an area of measles exanthem. Lancet 1978; i: 472-3.

${ }^{10}$ Kondo H, Rabin B S, Rodnan G P. Cutaneous antigenstimulating lymphokine production by lymphocytes of patients with progressive systemic sclerosis (scleroderma). J Clin Invest 1976; 58: 1388-94.

11 Cooper S M, Friou G J. Cytotoxicity in progressive systemic sclerosis: no evidence for increased cytotoxicity against fibroblasts of different origin. J Rheumatol 1979; 6: 25-9.

12 Wright J K, Hughes P, Rowell N R, Sneddon I B. Antibodydependent and phytohaemagglutinin-induced lymphocyte cytotoxicity in systemic sclerosis. Clin Exp Immunol 1979; 36: 175-82.

${ }^{13}$ Kaplan J, Callewaert D M. Expression of human T-lymphocyte antigens by natural killer cells. $J$ Natl Cancer Inst 1978; 60: $961-4$.

14 Masucci G, Poros A, Seeley J K, Klein E. In vitro generation of K 562 killers in human T-lymphocyte subsets. Cell Immunol 1980; 52: 247-54.

${ }^{15}$ Lipinski M, Tursz T, Kreis H, Finale Y, Amiel J. Dissociation of natural killer cell activity and antibody-dependent cell-mediated cytotoxicity in kidney allograft recipients receiving high-dose immunosuppressive therapy. Transplantation 1980; 29: 214.

${ }_{16}$ Pross H F, Baines M G. Spontaneous human lymphocytemediated cytotoxicity against tumour target cells. Cancer Immunol Immunother 1977; 3: 75-85.

${ }^{17}$ Kärre K, Klein G O, Keissling R, Klein G, Roder J C. Low natural in vivo resistance to syngeneic leukaemias in natural killerdeficient mice. Nature 1980; 284: 624-6

18 Talmadge J E, Myers K M, Prieur D J, Starkey J R. Role of NK cells in tumour growth and metastasis in beige mice. Nature 1980; 284: 622-4.

19 Lipinski M, Virelizier J L, Tursz T, Ǵriscelli C. Natural killer and killer cell activities in patients with primary immunodeficiencies 
or defects in immune interferon production. Eur $J$ Immunol 1980; 10: 246-9.

${ }^{20}$ Talbott J H; Barrocas M. Carcinoma of the lung in progressive systemic sclerosis: a tabular review of the literature and a detailed report of the roentgenographic changes in two cases. Semin Arthritis Rheum 1980; 9: 191-217.
${ }^{21}$ Duncan S C, Winkelmann R K. Cancer and scleroderma. Arch Dermatol 1979; 115: 950-5.

22 Svedmyr E, Jondal M. Cytotoxic effector cells specific for B cell lines transformed by Epstein-Barr virus are present in patients with infectious mononucleosis. Proc Natl Acad Sci USA 1975; 72: $1622-6$. 